\title{
DIGLOSIA
}

Terakreditasi Sinta 3 | Volume 3 | Nomor 2 | Tahun 2020| Halaman 221-228

P-ISSN 2615-725X | E-ISSN 2615-8655

http://diglosiaunmul.com/index.php/diglosia/article/view/48

\section{PENERAPAN MACROMEDIA FLASH DALAM MENINGKATKAN KREATIVITAS, HASIL BELAJAR, DAN EFEKTIVITAS PEMBELAJARAN SISWA KELAS XII DI SMK NEGERI 1 KALIORANG}

\author{
The Use of Macromedia Flash to Increase Creativity, Learning Outcome, and the Effectiveness of \\ Learning in Class XII SMK Negeri 1 Kaliorang
}

\author{
Rudi Hartono ${ }^{1, *}$, Susilo ${ }^{2}$, Yusak Hudiyono ${ }^{3}$ \\ ${ }^{1,2,3}$ Program Magister Pendidikan Bahasa dan Sastra Indonesia \\ Fakultas Keguruan dan Ilmu Pendidikan, Universitas Mulawarman \\ Pos-el korespondensi: rudifcb9@gmail.com
}

\begin{abstract}
Indonesian subjects have different levels of difficulty so there needs to be variations in learning, so students do not get bored. To implement the objectives of the Indonesian language subject, Indonesian language learning in the 2013 curriculum is presented using a text-based approach. In addition, the use of instructional media in the learning process will reduce student dependence on teachers. The implementation of learning media aims to (1) how is the application of learning media macromedia flash in improving student learning creativity in Indonesian language lessons; (2) how is the application of macromedia flash learning media in improving student learning outcomes in Indonesian language lessons; and (3) how is the effectiveness of macromedia flash learning media in increasing creativity and student learning outcomes in Indonesian language lessons. The subjects of this study were students of class XII at SMK Negeri 1 Kaliorang. This type of research is included in the Classroom Action Research (CAR) whose steps are as follows (1) planning, (2) implementation; (3) observation, and (4) reflection. Retrieval of research data through observation, written tests, and questionnaires with research instruments in the form of (1) observation sheets, (2) test questions, and (3) questionnaire sheet. After conducting research Application of audio-visual learning media can improve student learning outcomes in class XII SMK Negeri 1 Kaliorang, the learning outcomes are evidenced by an increase in test results at the end of each cycle. Improved learning outcomes seen from mastery learning in the first cycle that is $53.33 \%$ and $83.33 \%$ in the second cycle.
\end{abstract}

Keywords: macromedia flash learning media, classroom action research, creativity, effectiveness, student learning outcomes

\begin{abstract}
Abstrak: Mata pelajaran Bahasa Indonesia memiliki tingkat kesulitan yang berbeda sehingga perlu adanya variasi dalam pembelajaran agar siswa tidak jenuh. Untuk mengimplementasikan tujuan mata pelajaran Bahasa Indonesia tersebut, maka pembelajaran bahasa Indonesia dalam kurikulum 2013 disajikan dengan menggunakan pendekatan berbasis teks. Selain itu penggunaan media pembelajaran dalam proses pembelajaran akan mengurangi ketergantungan siswa terhadap guru. Implementasi media pembelajaran ini bertujuan untuk (1) mendeskripsikan penerapan media pembelajaran macromedia flash dalam meningkatkan kreativitas belajar siswa pada pelajaran Bahasa Indonesia; (2) mendeskripsikan penerapan media pembelajaran macromedia flash dalam meningkatkan hasil belajar siswa pada pelajaran Bahasa Indonesia; (3) mendeskripsikan keefektivitasan media pembelajaran macromedia flash dalam meningkatkan kreativitas dan hasil belajar siswa pada pelajaran Bahasa Indonesia. Subjek penelitian ini adalah siswa kelas XII di SMK Negeri 1 Kaliorang. Jenis penelitian ini termasuk dalam PTK (Penelitian Tindakan Kelas) yang langkahnya sebagai berikut: (1) perencanaan, (2) pelaksanaan, (3) observasi, dan (4) refleksi. Pengambilan data penelitian melalui observasi, tes tertulis, dan angket dengan instrumen penelitian berupa: (1) lembar observasi; (2) soal tes, dan (3) lembar angket. Setelah melakukan penelitian Penerapan media pembelajaran audio visual dapat meningkatkan hasil belajar siswa kelas XII SMK Negeri 1 Kaliorang, hasil belajar tersebut dibuktikan dengan peningkatan hasil tes pada setiap akhir siklus. Peningkatan hasil belajar dilihat dari ketuntasan belajar pada siklus I 53,33\% dan pada siklus II 83,33\%.
\end{abstract}

Kata kunci: media pembelajaran macromedia flash, penelitian tindakan kelas, kreativitas, efektivitas, hasil belajar siswa 


\section{A. PENDAHULUAN}

Proses belajar mengajar yang baik ditentukan oleh seorang guru dan siswa sebagai individu yang terlibat langsung di dalam proses belajar mengajar. Keberhasilan siswa dalam belajar tergantung dari keberhasilan guru dalam penyampaian materi belajar. Jadi kesiapan guru dalam mengajar dan kemampuan guru dalam menguasai materi ajar sangat memegang peranan yang sangat penting dalam keberhasilan belajar siswa. Untuk itu diperlukan suatu metode pembelajaran yang dapat meningkatkan kreativitas, hasil belajar dan efektivitas siswa dalam belajar.

Peneliti melakukan observasi pada kelas XII Administrasi Perkantoran di SMK Negeri 1 Kaliorang dengan jumlah 30 siswa. Pada saat berlangsungnya kegiatan proses belajar mengajar di kelas teori khususnya pada mata pelajaran Bahasa Indonesia menunjukkan kreativitas dan efektivitas siswa rendah dalam mengikuti proses belajar mengajar. Hal ini ditunjukkan dengan (1) pada saat proses pembelajaran ada beberapa siswa yang mengantuk dan tiduran, (2) pada saat pembelajaran berlangsung siswa cenderung pasif dalam belajar, siswa tidak mau bertanya dan belum ada keberanian siswa untuk menjawab pertanyaan yang diberikan oleh guru, (3) ada juga siswa yang bermain handphone saat proses pembelajaran, (4) dan saat guru menjelaskan materi, siswa banyak yang mengobrol sendiri di luar topik pembelajaran, sehingga menimbulkan kegaduhan dan pembelajaran di kelas menjadi tidak kondusif.

Kemungkinan hasil belajar yang rendah juga dapat dipengaruhi pada penggunaan metode pembelajaran teacher center yang cenderung monoton, sehingga sebagian siswa tidak memperhatikan guru mengajar saat pelajaran berlangsung. Keterbatasan pembelajaran di kelas khususnya pada mata pelajaran bahasa Indonesia secara teori cukup sulit dipahami, keterbatasan ini perlu didukung dengan adanya sarana media pembelajaran. Pemilihan media pembelajaran harus benar-benar tepat dan dapat mempermudah dalam penyampaian materi, agar semua pesan yang ingin disampaikan guru dapat diterima secara keseluruhan oleh siswa. Media pembelajaran merupakan suatu sarana komunikasi pembawa pesan dari sumber pesan kepada penerima pesan untuk menunjang proses pembelajaran. Media pembelajaran membuat pengajaran akan lebih menarik perhatian siswa. Materi pelajaran akan lebih jelas maknanya, sehingga akan lebih mudah dipahami oleh siswa. Media pembelajaran juga membuat metode mendidik akan lebih bervariasi, tidak semata-mata komunikasi verbal melalui penuturan kata-kata oleh guru sehingga siswa tidak bosan dan guru tidak kehabisan tenaga.

Pembelajaran konvensional umumnya hanya memusatkan pada metode pembelajaran seperti ceramah. Pada model pembelajaran ini, siswa diharuskan untuk menghafal materi yang diberikan oleh guru dan tidak untuk menghubungkan materi tersebut dengan keadaan sekarang (kontekstual). Freire (1999) memberikan istilah terhadap pengajaran seperti itu sebagai suatu penyelenggaraan pendidikan bergaya bank (banking concept of education). Kondisi yang demikian menuntut guru untuk lebih inovatif mencari atau membuat media pembelajaran yang menarik dan dapat menumbuhkan minat belajar siswa sehingga mendukung proses pembelajaran. Menurut Hernowo (2005) apabila di dalam diri seseorang tidak muncul gairah untuk mengajar atau belajar tentang hal-hal yang diajarkan atau dipelajarinya, maka di dalam lingkungan belajar mengajar itu agak sulit dikatakan ada kegembiraan. 


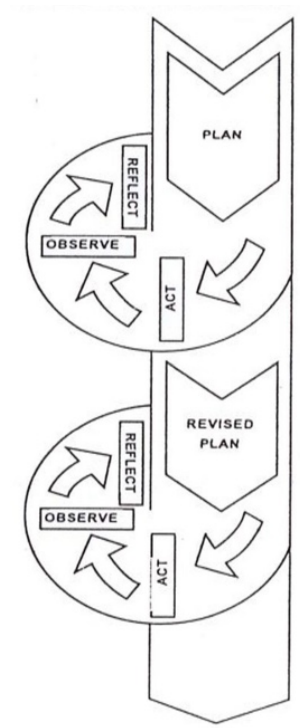

\section{Gambar 1. Siklus PTK menurut Kemmis \& Taggart (Kusumah \& Dwitagama, 2011)}

Untuk mengatasi masalah yang dijelaskan di atas, diperlukan strategi untuk meningkatkan motivasi belajar siswa berupa pemanfaatan media pembelajaran berbasis audio visual. Melalui media audio visual diharapkan indra penglihatan dan pendengaran berperan sepenuhnya dalam menangkap seluruh informasi pembelajaran, serta dapat meningkatkan kreativitas, efektivitas dan hasil belajar siswa supaya konsentrasi dalam proses pembelajaran lebih terfokus dan berusaha untuk meraih prestasi semaksimal mungkin. Media ini terdiri dari media visual yang disinkronkan dengan media audio, yang sangat memungkinkan terjalinnya komunikasi dua arah antara guru dan siswa di dalam proses belajar-mengajar.

Berdasarkan beberapa permasalahan tersebut, pada penelitian ini dipilih kelas XII Administrasi Perkantoran untuk dijadikan sampel penelitian dan perlu adanya suatu metode pembelajaran yang dapat meningkatkan motivasi siswa dan dapat memaksimalkan potensi yang dimiliki siswa sehingga prestasi belajar siswa dapat meningkat. Salah satunya adalah dengan penerapan media audio visual. Memperhatikan hal tersebut maka diperlukan penelitian yang menawarkan implementasi media audio-visual sebagai media pembelajaran. Penelitian ini dilakukan di SMK Negeri 1 Kaliorang karena pendidik masih menggunakan media pembelajaran yang bersifat tradisional, meskipun fasilitas pembelajaran yang tersedia di sekolah tersebut memadai sehingga pembelajaran belum menimbulkan rangsangan kreativitas siswa. Penggunaan media pembelajaran yang konvensional menyebabkan siswa mengalami kejenuhan yang berdampak pada kemampuan siswa dalam menganalisis. Hal tersebut menunjukkan pentingnya variasi pembelajaran yang memanfaatkan fasilitas kelas sebagai sumber belajar. Penelitian yang akan dilakukan oleh peneliti yaitu dengan menggunakan software Macromedia Flash 8. Materi yang akan disajikan menggunakan teori menganalisis teks novel dengan pemodelan teks sesuai kurikulum 2013.

Implementasi media pembelajaran ini bertujuan untuk (1) mendeskripsikan penerapan media pembelajaran macromedia flash dalam meningkatkan kreativitas belajar siswa pada pelajaran Bahasa Indonesia; (2) mendeskripsikan penerapan media pembelajaran macromedia flash dalam meningkatkan hasil belajar siswa pada pelajaran Bahasa Indonesia; (3) mendeskripsikan keefektivitasan media pembelajaran macromedia flash dalam meningkatkan kreativitas dan hasil belajar siswa pada pelajaran Bahasa Indonesia.

\section{B. METODE}

Model penelitian tindakan kelas yang digunakan dalam penelitian ini adalah model Kemmis \& McTaggart. Model penelitian ini menggabungkan dua komponen yaitu komponen acting (tindakan) dan observing (pengamatan) menjadi satu kesatuan. Hal ini dijelaskan 
oleh (Kusumah \& Dwitagama, 2011) bahwa penggabungan dua komponen ini karena proses tindakan dan pengamatan merupakan suatu kesatuan yang tidak bisa dilepaskan. Jadi, ketika melakukan suatu tindakan, saat itu pula peneliti melakukan pengamatan.

Siklus penelitian ini tergantung pada ketercapaian tujuan penelitian, apabila tujuan penelitian telah tercapai maka siklus selanjutnya tidak dilakukan. Setiap siklus akan terdiri dari 4 tahap, yaitu planning, acting, observasing, dan reflecting. Tahap planning (perencanaan) meliputi: (1) menyusun Rencana Pelaksanaan Pembelajaran (RPP), skenario proses pembelajaran, mempersiapkan materi yang akan disampaikan menggunakan media pembelajaran audio visual; dan (2) menyusun instrumen sebagai pengumpul data, berupa lembar observasi yang akan digunakan dalam penelitian, alat evaluasi yang berupa soal, dan angket sebagai menilai motivasi belajar siswa selama kegiatan belajar mengajar. Selanjutnya tahap acting (tindakan) meliputi: (1) membuka pelajaran; (2) melakukan presensi siswa; (3) memberikan media pembelajaran audio visual yang dipadukan dengan ceramah, diskusi antarsiswa dan tanya jawab atau jawab pertanyaan secara lisan; (4) memperjelas materi apa saja yang telah didapatkan; (5) memberikan dan mengumpulkan angket motivasi belajar; (6) memberikan tes untuk mengetahui tingkat pemahaman siswa terhadap pelajaran yang telah diberikan; dan (6) menutup pelajaran.

Tahap observasing (pengamatan), pengamat melakukan pengamatan pelaksanaan tindakan untuk mengetahui sejauh mana efek penerapan penggunaan media pembelajaran audio visual selama pelajaran berlangsung pada siswa yang dapat dilihat dari motivasi siswa dari hasil angket yang diisi oleh siswa dan prestasi dari hasil tes yang dikerjakan oleh siswa, hasil pelaksanaan tindakan kelas yang meliputi hasil observasi, angket, dan tes dianalisis yang hasilnya akan digunakan sebagai acuan untuk melaksanakan perbaikan pada siklus selanjutnya.

Tahap reflecting (refleksi) merupakan kegiatan mengulas secara kritis perubahan yang terjadi pada siswa, suasana di kelas dan guru. Dalam tahap ini, dianalisis kendala-kendala yang dihadapi dalam pembelajaran yang kemudian ditentukan langkah-langkah perbaikan untuk siklus selanjutnya dianalisis sehingga dapat diketahui apabila ada peningkatan motivasi dan prestasi belajar siswa saat siklus I. Jika tidak ada peningkatan, maka diadakan siklus II dengan perbaikan kualitas pembelajaran sehingga dapat tercapai tujuan pembelajaran yang ditandai dengan peningkatan gerak belajar siswa.

Penelitian ini dilaksanakan di SMK Negeri 1 Kaliorang yang beralamatkan di Jalan Ery Soeparjan, Desa Bukit Makmur, Kecamatan Kaliorang, Kabupaten Kutai Timur. Penelitian dilakukan pada semester genap tahun ajaran 2017/2018 tepatnya pada bulan Oktober 2017. Jadwal penelitian disesuaikan dengan jadwal proses pembelajaran yang berlangsung di SMK Negeri 1 Kaliorang. Subjek penelitian ini adalah siswa kelas XII di SMK Negeri 1 Kaliorang dengan jumlah siswa 30 siswa. Pemilihan subjek dilakukan secara purposive, yakni subjek penelitian ditentukan dengan tujuan meningkatkan kualitas pembelajaran dan pemahaman di kelas tersebut, yang selama ini proses pembelajaran yang dilakukan masih secara konvensional. Sasaran penelitian ini adalah motivasi dan prestasi belajar siswa terhadap mata pelajaran perbaikan dan perawatan mekanik otomotif menggunakan media audio visual.

\section{PEMBAHASAN}

Pada bagian ini akan dipaparkan hasil penelitian yang dilakukan, yaitu hasil dari siklus I dan siklus II, sesuai dengan PTK menurut Kemmis \& Taggart. 


\section{Siklus 1}

Berdasarkan hasil tes awal untuk mengetahui kreativitas siswa sebelum menggunakan media Macromedi Flash, maka diperoleh hasil yang diperlihatkan pada Tabel 1.

Tabel 1. Persentase Tes Kreativitas Siswasebelum Menggunakan Media Macromedi Flash

\begin{tabular}{|c|c|c|c|c|c|c|c|}
\hline No & Nilai & Frekuensi & $\begin{array}{c}\text { Nilai } \\
\text { Tengah (xi) }\end{array}$ & fixi & Persentase & Kategori & Keterangan \\
\hline 1 & $21-40$ & 2 & 31,5 & 31,50 & $7 \%$ & Tidak kreatif & Tidak tuntas \\
\hline 2 & $41-60$ & 12 & 51,5 & 309,00 & $40 \%$ & Kurang kreatif & Tidak tuntas \\
\hline 3 & $61-80$ & 14 & 71,5 & 500,50 & $47 \%$ & Kreatif & Tuntas \\
\hline 4 & $81-100$ & 2 & 91,5 & 91,50 & $7 \%$ & Sangat kreatif & Tuntas \\
\hline \multicolumn{2}{|c|}{ Jumlah } & 30 & & 932,50 & $100 \%$ & & \\
\hline \multicolumn{8}{|c|}{$\begin{array}{l}\text { Nilai rata-rata }=932,50 / 30=62,17 \\
\text { Ketuntasan klasikal }=8 / 30 \times 100 \%=58,13 \%\end{array}$} \\
\hline
\end{tabular}

Berdasarkan hasil tes kreativitas tersebut maka diperoleh data bahwa siswa kelas XII Administrasi Perkantoran SMK Negeri 1 Kaliorang terdiri dari 7\% siswa tidak kreatif, 40\% kurang kreatif, 47\% kreatif, dan $7 \%$ sangat kreatif dengan hasil rata-rata nilai tes kreativitas adalah 58,13. Hal ini berarti kreativitas siswa masih dalam kategori rendah sehingga perlu ditingkatkan.

Tes hasil belajar dilakukan setelah kegiatan pembelajaran pada siklus I berlangsung. Hasil tes disajikan pada Tabel 2.

Tabel 2. Hasil Tes pada Siklus I

\begin{tabular}{lcc}
\hline $\begin{array}{c}\text { Ketuntasan } \\
\text { Belajar }\end{array}$ & $\begin{array}{c}\text { Jumlah } \\
\text { Siswa }\end{array}$ & Persentase \\
\hline Tuntas & 16 & $53,33 \%$ \\
Tidak Tuntas & 14 & $47,83 \%$ \\
\hline Ketercapaian KKM (\%) & $\mathbf{5 3 , 3 3 \%}$ \\
\hline
\end{tabular}

Pada siklus I di atas, hasil tes belajar siswa menunjukkan belum mencapai persentase nilai KKM yang diharapkan. Persentase KKM yang dicapai siswa pada siklus I sebesar 53,33\% dengan rincian nilai 14 dari 30 siswa belum tuntas sehingga dapat dikatakan persentase KKM pada siklus I belum mencapai indikator keberhasilan dalam penelitian ini. Indikator keberhasilan penelitian yang ditetapkan sebesar $\geq 75 \%$, maka perlu adanya perbaikan pada siklus selanjutnya.

Setelah dilaksanakan pembelajaran dengan menggunakan macromedia flash pada siklus I, selanjutnya dilaksanakan refleksi terhadap pembelajaran yang telah berlangsung. Secara umum, pelaksanaan pembelajaran Bahasa Indonesia telah sesuai dengan RPP yang telah disusun. Namun demikian, masih terdapat beberapa hambatan yang muncul saat pelaksanaan yang perlu dilakukan perbaikan.

Berdasarkan hasil observasi pelaksanaan pembelajaran pada siklus I, terdapat beberapa aspek keberhasilan dan kelemahan. Aspek keberhasilan dan kelemahan pada siklus I digunakan sebagai informasi untuk melakukan perbaikan pada pelaksanaan siklus berikutnya. Aspek keberhasilan adalah media pembelajar audio visual telah melatih siswa untuk belajar secara nyata berdasarkan materi yang dipelajari. Sedangkan aspek kekurangan antara lain: (a) hasil rata-rata nilai tes kreativitas adalah 58,13. Ini berarti kreativitas siswa masih dalam kategori rendah sehingga perlu ditingkatkan; (b) hasil tes belajar siswa masih banyak yang belum mencapai nilai KKM. Beberapa siswa sering menggunakan kesempatan untuk 
bercanda dengan teman, dan menggunakan handphone sehingga beberapa kali terjadi kegaduhan di dalam kelas selama proses pembelajaran berlangsung; (c) berdasarkan hasil kreativitas dan hasil belajar siswa dapat dikatakan bahwa belum efektifnya pembelajaran menganalisis novel; dan (d) penataan meja dan kursi masih kurang pada saat proses pembelajaran.

Berdasarkan aspek kelebihan dan kekurangan tindakan dari siklus I, langkah-langkah perbaikan yang akan dilakukan pada siklus II adalah sebagai berikut: (a) guru melaksanakan pembelajaran dengan menggunakan media macromedia flash untuk meningkatkan kreativitas, hasil belajar dan efektivitas media pembelajaran siswa; (b) penataan kursi dan meja antar siswa diatur agar tidak terlalu berdekatan, sehingga siswa lebih fokus dalam proses pembelajaran; dan (c) guru meningkatkan pemantauan dan pengendalian kepada siswa pada saat pembelajaran menggunakan media audio visual.

\section{Siklus II}

Pada siklus II ini diadakan tes kreativitas siswa dan hasilnya cukup memuaskan karena menunjukkan adanya peningkatan dibandingkan hasil tes sebelumnya. Data tersebut diperlihatkan pada Tabel 3.

Tabel 3. Persentase Tes Kreativitas Siswa Siklus II

\begin{tabular}{|c|c|c|c|c|c|c|c|}
\hline No & Nilai & Frekuensi & $\begin{array}{c}\text { Nilai } \\
\text { Tengah (xi) }\end{array}$ & fixi & Persentase & Kategori & Keterangan \\
\hline 1 & $21-40$ & 0 & 0 & 0,00 & $0 \%$ & tidak kreatif & tidak tuntas \\
\hline 2 & $41-60$ & 2 & 51,50 & 103,00 & $6 \%$ & kurang kreatif & tidak tuntas \\
\hline 3 & $61-80$ & 14 & 71,50 & 1001,00 & $47 \%$ & kreatif & Tuntas \\
\hline 4 & $81-100$ & 14 & 91,50 & 1281,00 & $47 \%$ & sangat kreatif & Tuntas \\
\hline \multicolumn{2}{|c|}{ Jumlah } & 30 & & 2384,00 & $100 \%$ & & \\
\hline $\begin{array}{l}\text { Nilai } \\
\text { Ketu } \\
7 \% \text { t }\end{array}$ & $\begin{array}{l}\text { ta-rata }=23 \\
\text { asan klasik } \\
\text { k kreatif, } 7\end{array}$ & $\begin{aligned} & 00 / 30=7 \\
&= 28: 30 \times 10 \\
& \text { kurang kreat }\end{aligned}$ & $\begin{array}{l}0 \\
0=93 \% \\
47 \% \text { kreatif, }\end{array}$ & $47 \%$ san & kreatif & & \\
\hline
\end{tabular}

Berdasarkan tabel di atas maka dapat diketahui bahwa hasil tes kreativitas siswa pada siklus II ini menunjukkan terjadi peningkatan jika dibandingkan dengan hasil tes kreativitas pada siklus I. Pada siklus I terdiri dari 7\% siswa tidak kreatif, $40 \%$ kurang kreatif, $47 \%$ kreatif, dan 7\% sangat kreatif dengan hasil rata-rata nilai tes kreativitas adalah 58,13. hasil tes kreativitas siklus II menunjukkan nilai rata-rata hasil tes meningkat menjadi 79,50 dengan ketuntasan 93\%. Data siswa yang mendapat nilai $21-40$ tidak ada, nilai 41-60 ada 7\% dalam kategori kurang kreatif, nilai $61-80$ ada $47 \%$ dalam kategori kreatif, dan nilai $81-100$ ada $47 \%$ dalam kategori sangat kreatif.

Tes hasil belajar dilakukan setelah kegiatan pembelajaran pada siklus II berlangsung. Hasil tes disajikan pada Tabel 4.

Tabel 4. Hasil Tes pada Siklus II

\begin{tabular}{lcc}
\hline $\begin{array}{c}\text { Ketuntasan } \\
\text { Belajar }\end{array}$ & $\begin{array}{c}\text { Jumlah } \\
\text { siswa }\end{array}$ & Persentase \\
\hline Tuntas & 25 & $83,33 \%$ \\
Tidak Tuntas & 5 & $17,39 \%$ \\
\hline Ketercapaian KKM (\%) & $\mathbf{8 3 , 3 3 \%}$ \\
\hline
\end{tabular}

Data hasil tes tertulis siklus II yang disajikan pada tabel di atas menunjukkan adanya peningkatan, ketercapaian KKM sebesar 83,33\%. Peningkatan ketercapaian pada siklus II dapat dikatakan telah mencapai indikator keberhasilan.

Berdasarkan data hasil tes kreativitas siklus II menunjukkan nilai rata-rata hasil tes meningkat menjadi 79,50 dengan 
ketuntasan 93\%. Dan data hasil belajar siswa menunjukkan peningkatan dari siklus I sebesar $53,33 \%$ menjadi $83,33 \%$. Sehingga pembelajaran menganalisis teks novel pada kelas XII Administrasi Perkantoran menggunakan macromedia flash berjalan dengan efektif.

Berdasarkan hasil observasi pelaksanaan pembelajaran pada siklus II, menunjukkan bahwa secara umum pembelajaran yang dilaksanakan pada siklus II telah berjalan sesuai dengan yang direncanakan. Pada pelaksanaan pembelajaran siklus II terdapat beberapa aspek keberhasilan dan kelemahan. Aspek keberhasilan dan kekurangan pada siklus II sebagai berikut. Aspek keberhasilan antara lain: (a) media pembelajaran macromedia flash telah melatih siswa untuk belajar secara nyata berdasarkan materi yang dipelajari; (b) kegiatan pembelajaran dengan menggunakan macromedia flash berjalan dengan baik; (c) hasil tes kreativitas siklus II menunjukkan nilai rata-rata hasil tes meningkat menjadi 79,50 dengan ketuntasan 93\%; (d) ketercapaian KKM pada tes hasil belajar siklus II mencapai 83,33\%; dan (e) berdasarkan hasil data kreativitas dan hasil belajar siswa dapat dikatakan bahwa penerapan macromedia flash sangat efektif. Sedangkan aspek kekurangan adalah kegiatan pembelajaran berlangsung dengan baik, namun masih ada beberapa siswa yang kurang aktif ketika mengikuti kegiatan pembelajaran.

Berdasarkan data pelaksanaan tindakan siklus II dalam upaya peningkatan hasil belajar siswa yang disajikan menunjukkan pencapaian yang optimal dengan tercapainya indikator keberhasilan penelitian. Berdasarkan karakteristik penelitian tindakan kelas, apabila telah tercapai keadaan yang lebih baik setelah dilakukan tindakan maka penelitian dapat dihentikan sehingga penelitian ini diberhentikan pada siklus II.

\section{PENUTUP}

Media pembelajaran audio visual dapat meningkatkan kreativitas siswa kelas XII SMK Negeri 1 Kaliorang, hal ini dapat dilihat dari indikator proses pembelajaran menunjukkan tingkat partisipasi pada ketujuh aspek indikator yaitu memperhatikan, mencatat, bertanya, menjawab pertanyaan, mengemukakan pendapat, mendiskusikan materi, kemandirian belajar. Tingkat partisipasi siswa setelah menggunakan media pembelajaran audio visual pada siklus I sebesar $82 \%$ pada aspek memperhatikan, $34 \%$ pada aspek mencatat, $13 \%$ pada aspek bertanya, 21\% pada aspek menjawab pertanyaan, 43\% pada aspek mengemukakan pendapat, $17 \%$ pada aspek mendiskusikan materi, 78\% pada aspek kemandirian belajar. Terjadi peningkatan pada siklus II, yaitu sebesar 95\% pada aspek memperhatikan, 56\% pada aspek mencatat, $43 \%$ pada aspek bertanya, $34 \%$ pada aspek menjawab pertanyaan, $52 \%$ pada aspek mengemukakan pendapat, $34 \%$ pada aspek mendiskusikan materi, 86\% pada aspek kemandirian belajar. Dilihat dari indikator produk 95,65\% tanggapan siswa sangat positif dan 4,35\% tanggapan siswa positif.

Pemanfaatan multimedia pembelajaran yang dikembangkan ini terbatas pada sekolah-sekolah yang memiliki fasilitas komputer. Sebaiknya, guru memahami terlebih dahulu petunjuk penggunaan media dan fungsi-fungsi tombol yang ada pada media pembelajaran sebelum digunakan secara klasikal. Begitu pula, pada pembelajaran yang sifatnya mandiri, sebaiknya siswa memperhatikan petunjuk penggunaan media dan petunjuk dalam mengerjakan soal evaluasi sebelum menggunakan media pembelajaran. 


\section{DAFTAR PUSTAKA}

Ciptono \& Kusuma, G. T. B. K. (2010). Guru Luar Biasa, Yogyakarta: Bentang Pustaka.

Dimyati dan Mudjiono. 1999. Belajar dan Pembelajaran. Jakarta: Rineka Cipta.

Freire, P. (1999). Menggugat Pendidikan. Yogyakarta: Pustaka Pelajar.

Hernowo. (2005). Menjadi Guru yang Mau dan Mampu Mengajar secara Menyenangkan. Bandung: Mizan Learning Center.

Kusumah, W. \& Dwitagama, D. (2011). Mengenal Penelitian Tindakan Kelas. Edisi 2. Jakarta: Indeks.

Mulyo, S., Ilyas, M., \& Ridhani, A. (2019). Pembelajaran Keterampilan Berbicara Dengan Metode Field Trip Pada Peserta Didik Kelas IX SMP Samarinda. Diglosia: Jurnal Kajian Bahasa, Sastra, Dan Pengajarannya, 2(2), 115-126. https://doi.org/10.30872/diglosia.v 2i 2.23

Munandar, U. (2004). Pengembangan Kreativitas Anak Berbakat. Jakarta: Rineka Cipta.

Ranem. (2018). Pengembangan Bahan Ajar Materi Debat Dengan Metode Role Playing Pada Siswa Kelas X Sekolah Menengah Atas .Diglosia: Jurnal Kajian Bahasa, Sastra, Dan Pengajarannya, 1(2), 65-74. https://doi.org/10.30872/diglosia.v $1 \mathrm{i} 2.10$
Rohendi, D., Sutarno, H., \& Nopiyanti. (2010). Penerapan Model Pembelajaran Kooperatif Tipe Teams Games Tournament Berbasis Multimedia dalam Meningkatkan Hasil Belajar Siswa pada Mata Pelajaran Teknologi Informasi dan Komunikasi. Jurnal Pendidikan Teknologi Informasi dan Komunikasi (PTIK), 3(1), 19-22.

Sari, L. K. (2019). Pengembangan Pembelajaran Menulis Teks Ceramah Dengan Model Problem Based Learning Dipadukan Media Gambar Pada Siswa Kelas XI SMA. Diglosia: Jurnal Kajian Babasa, Sastra, Dan Pengajarannya, 2(1), 59-72. https://doi.org/10.30872/diglosia.v $2 \mathrm{i} 1.18$

Slameto. (2013). Belajar dan Faktor-Faktor yang Mempengarubinya. Jakarta: Rineka Cipta.

Surakhmad, W. (2009). Pengantar Penelitian Ilmiah. Bandung: Tarsito.

Sutriyati. (2019). Pengembangan Bahan Ajar Menulis Esai Dengan Memanfaatkan Kearifan Lokal Melalui Pembelajaran Berbasis Proyek (PBP) Siswa SMA. Diglosia: Jurnal Kajian Bahasa, Sastra, Dan Pengajarannya, 2(1), 39-46. https://doi.org/10.30872/diglosia.v $2 \mathrm{i} 1.16$ 